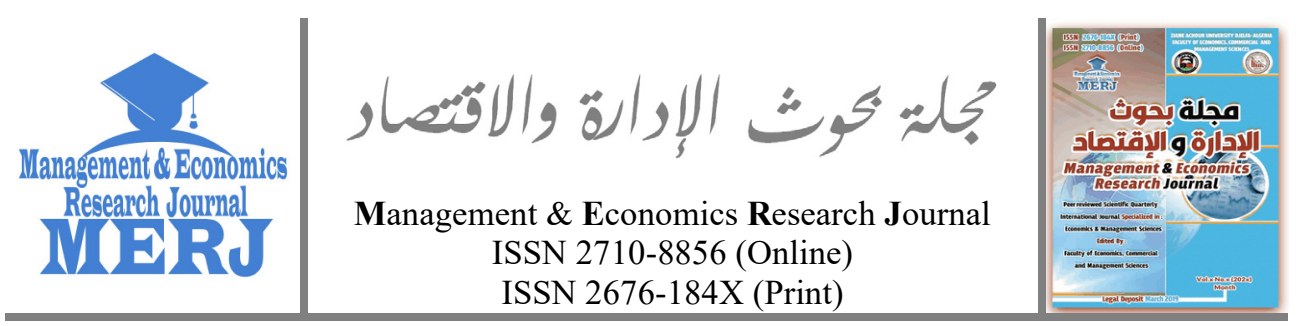

Vol. 3 No. 1 (2021), pp. 60-75

https://doi.org/10.48100/merj.2021.153

Check for updates

\title{
The Mediating Role of Institutional Trust on Corporate Image and Customer Trust in Iraqi Banking Sector
}

\author{
Hamid Mohsin Jadah ${ }^{1}$ (D), Manar Hayder Ali Alghanimi ${ }^{2}$, \\ Noor Hashim Mohammed Al-Husainy ${ }^{3}$ (D) \\ ${ }^{1}$ Senior Lecturer, Department of Finance and Banking, College of Administration and \\ Economics, University of Kerbala (Iraq) \\ $\triangle$ hamed.m@uokerbala.edu.iq \\ ${ }^{2}$ Master of Banking Science, Lecturer, Babylon Technical Institution, AL-Furat AL-Awsat \\ Technical University (Iraq) \\ $\triangle$ alganimymanar@gmail.com \\ ${ }^{3}$ Master of Banking Science, Lecturer, Imam AL-Kadhum College for Islamic Studies, \\ Babylon Departments (Iraq) \\ $\bowtie$ noorhashim136@gmail.com
}

\begin{tabular}{lll}
\hline Received: 05-02-2021 Accepted: 05-03-2021 & Published online: 08-03-2021 \\
\hline
\end{tabular}

\section{How to Cite:}

Jadah, H. M., Alghanimi, M. H. A., \& Al-Husainy, N. H. M. (2021). The Mediating Role of Institutional Trust on Corporate Image and Customer Trust in Iraqi Banking Sector. Management \& Economics Research Journal, 3(1), 60-75. https://doi.org/10.48100/merj.2021.153

\begin{abstract}
:
In today's highly volatile environment, banks strive to leverage the perceptions of their multiple customers more than ever before to build a sustainable competitive advantage. Accordingly, corporate image and customer trust concepts are vital for academicians and practitioners concerning their potential impact on internal and external stakeholders. Recognizing the intensified significance of a multi-stakeholder perspective,
\end{abstract}

- Corresponding author: Department of Finance and Banking, College of Administration and Economics, University of Kerbala (Iraq).

[ $\square$ hamed.m@uokerbala.edu.iq]

(C)2021 the Author(s). This is an open-access article distributed under the terms of (CC BY-NC 4.0) which permits use, distribution and reproduction in any medium, provided the original work is properly cited and is not used for commercial purposes. 
Jadah, H. M., Alghanimi, M. H. A., \& Al-Husainy, N. H. M.

the current study attempts to contribute to the literature by examining the mediating role of institutional trust on the relationship between corporate image and customer trust. The study applies the partial least squares structural equation modelling (PLS-SEM) method to examine this relationship. The data are collected from 372 Iraqi banking customers using a random sampling technique. The finding for path-1 shows a positive and significant association between corporate image, institutional trust, and trust in online banking services. Similarly, the result of path- 2 also reveals a positive and significant association between institutional trust and trust in online banking services. Finally, bias-corrected bootstrapping confirms that institutional trust plays a mediating role between corporate image and trust in online banking services in Iraq. This study has important theoretical and practical implications. It not only fills some of the gaps in the literature about trust in online banking services, particularly for Iraq, but it also reinforces to policymakers that institutional trust is an important factor in promoting customers' trust in financial services.

Keywords: Corporate Image, Customer Trust, Institutional Trust, Iraqi Banking Sector.

JEL Codes: L15, L19, L84

\section{Introduction}

The banking sector holds a prominent position in any economy. It provides necessary resources for entrepreneurs to carry out economic activities that will result in higher per capita income, improved saving rates, higher economic growth, and a greater diversity of products and services (Adams, Andersson, Andersson, \& Lindmark, 2009). However, can only be secure the social and economic benefits of the banking sector can only be secured in a stable and trustworthy business environment. Recently, deputy governor Ahmad Buraihi Ali of Central Bank Iraq (CBI) stressed that the bank's mandate is to foster monetary and financial stability. Still, we live in a world where there are extraordinary circumstances. After the global financial crisis, the monetary and financial conditions raised financial uncertainties and seriously affected the customer's trust level (Ali, 2018). Globalization, regulatory and political developments, and financial and economic integration have a far wider international reach and repercussions; social media, and the internet, which have become deeply ingrained in daily lives, have opened numerous opportunities and threats for companies from a marketing perspective.

Like any other economy, the banking sector is vital for the Iraqi economy and helps direct resources to productive entrepreneurial activities, 
\begin{tabular}{l|l|l} 
Management \& Economics Research Journal & Vol. 3 No. 1 (2021) & pp. 60-75 \\
\hline
\end{tabular}

reduce asymmetric information, transfer risk, and facilitate trade (Jadah, Mohammed, Hasan, \& Adetayo, 2020). However, the banking sector is facing an unstable environment due to the international financial crunch, technological advancement, competition, political instability, turbulent business environment, civil war, US invasion, and ISIS emergence. Further, the maturity of the Iraqi population is not provided with banking facilities (Jadah, Alghanimi, Al-Dahaan, \& Al-Husainy, 2020). The events above further damaged the already shaky trust of banking customers in Iraq. The banking sector in Iraq must formulate a financial strategy to cope with challenges and devise marketing and advertisement policies to educate, retain, and build customers' trust in banking services (Adeniran, Jadah, \& Mohammed, 2020). To keep pace with international competition and to increase reach, Iraqi banks also adopted an internet banking system; however, according to the International Monetary Fund (2019) report, the Iraqi banking sector failed to attract new customers and build trust in banking services due to poor infrastructure, shaky corporate image, and institutional setting (IMF, 2019). Despite numerous social and economic benefits of the financial sector, banking services usability among Iraqis is very low (see Jadah, Murugiah, \& Adzis, 2016), and Moin, Devlin, and McKechnie (2017) claimed that poor trust in financial services is one of the significant reasons for lower online-banking penetration. Therefore, the key objective of the current paper is to explore the association between firm image and trust in online banking services with the mediating role of institutional trust.

In this context, the remainder of this paper is structured as follows. Section two illustrates a brief overview of the literature. Section three presents the methodology. Section four outlines the findings and discussion. Section five illustrates the conclusion of this study.

\section{Literature Review}

This section discusses the previous literature that has been carried out in the domain of online banking. It includes an in-depth analysis of studies exploring institutional trust, corporate image, and trust in online services, mainly banking services.

Various explanations of the word trust show how complicated the concept is. In the organizational trust literature, it is found that trust is the expectation or belief about the trusted party or the willingness of the trustee to rely on another party. It is the behavioural intention to depend on the sense of risk or vulnerability in case the trust is violated (Yu, Balaji, \& Khong, 2017). Similarly, online trust is explained as the expectation of the 
Jadah, H. M., Alghanimi, M. H. A., \& Al-Husainy, N. H. M.

customer to deliver those expectations and believe in the command possessed by the site. Trust is developed when there are positive impressions of the customers about the electronic site, and the customers are also willing to take ownership of the vulnerability. The definition of trust is mainly related to the security of the trustee. It is related to the online banking environment with the actions performed by the customer in an online setup, and the user expects the internet to fulfil the needs. It is stated by Sikdar, Kumar, and Makkad (2015) that the level of adoption of online banking by customers is highly dependent on trust, institutional and positive corporate image.

Wang, Ngamsiriudom, and Hsieh (2015) find that trust in organizations changes over time. It follows a three-stage process that includes the construction of trust, constancy if trust exists already, and dissolution leading to a decline in trust. Institutional trust plays a crucial role in developing and maintaining a successful relationship between banks and customers. This is particularly significant because of the complexity of the financial products. It can be said that customer trust in online banking indicates the negative influence of the belief that there is a high level of risk in which the transaction is made. Hence, institutional trust acts as insurance against unexpected behaviours and underlying risks.

Pauline, Esterik-Plasmeijer, and Raaij (2017) classify trust as relational, calculus, and institutional. Relational trust is developed continuously as the relationships between the trustee and trustor are gradually established. This type of trust mainly depends on the knowledge from confiding with the trustor. Calculus-based trust is a communicational attribute in financial dealings and is based on logical choice as it is formed after careful evaluation of the profits. The third type of trust, institutional trust, is based on the institutional factors that operate on broad trust supports that preserve further risk-taking and trusting behaviour. Both relational and calculus-based trust developed from institutional-based trust.

In contrast to earlier classifications, Moin et al. (2017) categorized trust into three classes such as interpersonal, dispositional, and institutional trust. Ennew et al. (2011) claimed that financial service providers should consider five essential characteristics: shared values, competencies and expertise, consistency and integrity, communication, concern, and benevolence to increase customers' trust in their services. According to Mcknight, Choudhury, and Kacmar (2000), institutional trust depends on two critical attributes for financial service situational normality and structural assurance. The situational trust comprises an online banking system, whereas structural assurance is about regulation, legal protection, 
and data encryption. Both of these features would positively affect the trust intention of customers of financial services. Fuglsang and Jagd (2015) stated that the usage of online banking services is dependent on the trust of that individual in the internet. Due to the high risk and distrust prevailing in online banking, as the chances of being hacked are very high, online transactions, particularly financial ones, are naturally risky and dangerous. Hence, the trust in the institution decides the extent to utilize the banking service.

Online banking security is a major challenge for banks considering recent security breaches that reveal customer concerns about online transactions and the vulnerability of online information (Sikdar et al., 2015). Online banking consists of complex interactions between a number of entities, such as financial institutions, legislatures, and system designers, thus affecting the understanding of an individual. Hence, the perception of the bank at the institutional level (as a bank), as well as the system level (internet as a channel), has to be carefully assessed (McNeish, 2015). Several studies have mentioned the factors that influence trust in onlinebanking services. For instance, Alalwan, Dwivedi, Rana, and Williams (2016) stated that the assessment of the seller's security and the electronic commerce system's examination directly affects the users' tendency to use online banking services. Other methods of making customers trust the services include security warnings, seals, and guides to safety practices (Koksal, 2016). However, the institutional use and name recognition, corporate image of the company, is the best method as the formerly mentioned methods are seen as general internet security and are not always related by the customer to the institution. Wang et al. (2015) found that customers require a very high trust level for executing online financial transactions and customers also require information regarding institutional factors and the service provider's image to establish a long-term relationship. Similarly, Oliveira et al. (2017) and Yang, Chen, and Wei (2015) also revealed that the tendency to trust online services highly depends on the company's image.

The term firm image is the customer's response to the total offering and is the sum of the public's ideas, impressions, and beliefs about a certain organization. Corporate image is the function of the collection of experiences of purchasing and consumption made over time (Bruggen, 2014; Zameer, Tara, Kausar, \& Mohsin, 2015). As Melewar, Gupta, Kitchen, and Foroudi (2017) explain, the corporate image can also be understood as the result of communication that the organization sets up with the customers to spread a particular message. This message reflects the 
Jadah, H. M., Alghanimi, M. H. A., \& Al-Husainy, N. H. M.

vision, mission, strategic intention, goals as well as core values of the institution. According to Horng, Liu, Chou, Tsai, and $\mathrm{Hu}$ (2018), the corporate image has four aspects: screening, subjectivity, elaboration, and changeability. Mostafa (2017) said that the subjective impression of the institution and the activities of the same relate to customers' attitudes. Hence, it is clear that the firm image significantly influences customer behaviour and trust. Melewar et al. (2017) reinforce that a firm image directly impacts the customers' trust as it allows positive influence on not only potential customers but also employees, investors, and analysts.

Two principal components of the corporate image are functional and emotional. The first component relates to the tangible attributes and thus can be easily measured. In contrast, the second component relates to the psychological attributes associated with the attitudes and feelings toward the organization. Hence, the emotional attribute is based on individual experiences and the information processing of the attributes of the functional indicators of corporate image. Also, classify the corporate image as the summation of functional and emotional factors that includes contacting experience with the organization and any inexperienced information such as prediction, advertising, and word-of-mouth. According to Zameer et al. (2015), reliability and integrity between the partners are essential to developing trust.

Similarly, electronic banking adoption and commitment depend on trust in online banking services. It is concluded by Rahi (2015) that transaction-specific uncertainty, as well as other related risks of banks behaving opportunistically, is reduced when trust in electronic banking is high and the banking firm can deliver the expected outcomes. Interaction also becomes less complex when people assume that the party they trust behaves as they expect them to do. Another set of studies by Dauda and Lee (2015) and Oliveira et al. (2017) has shown that trust is highly critical to stimulating banking operations online as trust becomes a necessary component when individuals assume the presence of uncertainty. On the other hand, the customer is not keen to carry out online banking services if there is no technology trust. McNeish (2015) said that the dimensions of security services enhance technology trust, whereas the dimensions indicate authentication, confidentiality mechanisms, and access control systems. The capability process based on the accuracy, privacy, accountability, and authenticity of these authorizing parties and transactions highly supports the technology trust. History of the positive corporate image serves as a tool of self-verification as the image is transformed into trust as said by Horng et al. (2018) that when the customers have in mind a positive schema of the 
\begin{tabular}{l|l|l} 
Management \& Economics Research Journal & Vol. 3 No. 1 (2021) & pp. 60-75
\end{tabular}

brand, then it ultimately leads to higher customer satisfaction and that the trust of the customer is the key to make actual purchase or utilization of services. Based on the literature, the framework and the hypotheses are developed as follows:

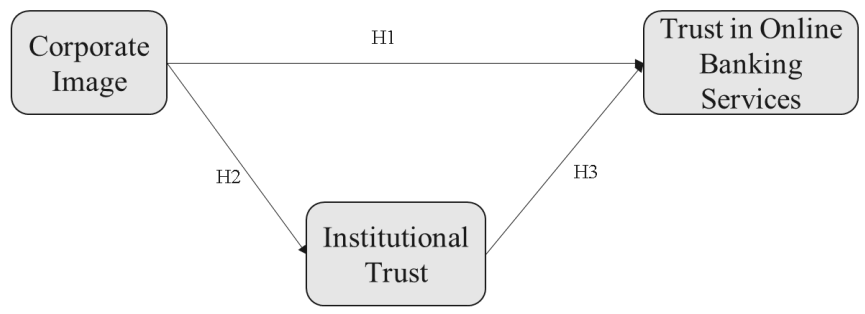

Figure 1. The Study Framework

\section{Methodology}

This study explored the association between corporate image and customer trust in the Iraqi banking sector with the mediating impact of institutional trust. A five-point Likert scale questionnaire is utilized to collect data from 410 banking customers for the banks that work in Iraq, and the questionnaire is adapted from the studies of Alvin (2017), Bruggen (2014), and Moin et al. (2017). The current paper utilized the same methodology as Hair et al. (2017). The partial least quadratic structural equation (PLS-SEM) technique is utilized to check the hypothesis. The PLS-SEM methodology is superior to other statistical techniques, such as the number of sample size constraints, efficiency in constructing the mathematical model, estimation, accuracy in calculations, and soft modelling assumptions (Hair et al., 2017). In addition, SEM integrates two powerful statistical methods: exploratory and structural path analysis, allowing the simultaneous evaluation of the metrics model.

\section{Findings and discussion}

This section illustrates the findings; 450 questionnaires were distributed in the Iraqi banking sector, the authors received back 382 questionnaires, and twelve were excluded because of high missing values. Therefore, a total of 372 questionnaires were used to examine the hypothesis. Descriptive statistics are presented below.

As can be seen from the results presented in table $1,57.26 \%$ of the respondents were males, and the majority, 49.73\%, were between 30-39 years old. It is also apparent and quite interesting that most respondents 
Jadah, H. M., Alghanimi, M. H. A., \& Al-Husainy, N. H. M.

were business people and job holders. This is critical because most banking services/products take care of the needs of workers and companies. The product of Cronbach's Alpha is presented below.

Table 1. The descriptive statistics

\begin{tabular}{|c|c|c|c|c|c|c|c|c|c|}
\hline \multirow[b]{2}{*}{ Measures } & \multicolumn{2}{|c|}{ Gender } & \multicolumn{4}{|c|}{ Age group } & \multicolumn{3}{|c|}{ Nature of customers } \\
\hline & Male & Female & $20+$ & $30+$ & $40+$ & $\begin{array}{l}50 \& \\
\text { above }\end{array}$ & $\begin{array}{l}\text { Job } \\
\text { holders }\end{array}$ & Businessman & Other \\
\hline Frequency & 213 & 159 & 68 & 185 & 73 & 46 & 104 & 237 & 31 \\
\hline Percentage & 57.26 & 42.74 & 18.27 & 49.73 & 19.62 & 12.36 & 27.95 & 63.70 & 08.33 \\
\hline
\end{tabular}

Previous studies, such as Litzinger et al. (2005), argued that Cronbach Alpha value, if higher than 0.6, would be assumed sufficient to assure the scale's reliability and internal consistency. The Cronbach's alpha findings revealed that neither was less than 0.70. All variables, therefore, have internal solid stability and trustworthiness. It is apparent from the findings presented in Table 2 that the value of Cronbach Alpha is more significant than 0.6 for all variables, hence, providing us reasonable grounds to believe that the adopted questionnaire has good internal consistency and reliability.

Table 2. Cronbach's alpha

\begin{tabular}{lcccc}
\hline Variable & $\begin{array}{l}\text { Number of } \\
\text { items }\end{array}$ & Cronbach's alpha & CR & AVE \\
\hline Institutional trust & 05 & 0.80 & 0.72 & 0.85 \\
Corporate image & 11 & 0.69 & 0.69 & 0.71 \\
Trust in online banking Services & 08 & 0.76 & 0.75 & 0.81 \\
\hline
\end{tabular}

The robustness of results largely depends on data normality. Tabachinich and Fidell (2007) argued that the elementary hypothesis of the regression analysis is that "each variable and all linear groupings of the variable are normally distributed". Statistical techniques such as the Shapiro-Wilk test, skewness, Kurtosis, or graphical approach such as Q-Q graphs may be utilized to check the normality of data. D'agostino et al. (1990) argued that the Shapiro-Wilk test has weak predictability power compared to skewness and Kurtosis; therefore, Skewness and Kurtosis were utilized to test the normality of data for the current study. The following Table illustrates the Skewness and Kurtosis Test. 
\begin{tabular}{l|l|l|} 
Management \& Economics Research Journal & Vol. 3 No. 1 (2021) & pp. 60-75 \\
\hline
\end{tabular}

Table 3. The Skewness and Kurtosis test

\begin{tabular}{lllll}
\hline Variables & \multicolumn{2}{l}{ Skewness } & Kurtosis & \\
& Std. Deviation & Value & Std. Deviation & Value \\
\hline Corporate image & 0.579 & 0.43 & \multirow{2}{*}{0.293} & 0.34 \\
Institutional trust & 0.28 & & 0.61 \\
Trust in online banking services & & 0.59 & & 0.21 \\
\hline
\end{tabular}

A dataset would be normally distributed if Skewness and Kurtosis values were between -1 and +1 (D'agostino et al., 1990). Table 3 shows that the values of all the variables fall between -1 and +1 . Hence, we assume that the data is normally distributed. Moreover, the current paper performed a Pearson correlation to gauge the association between corporate image, institutional trust, and trust in online banking services. The results are presented below.

Table 4. Correlation matrix

\begin{tabular}{llll}
\hline & $\begin{array}{l}\text { Trust in online-banking } \\
\text { services }\end{array}$ & Corporate image & Institutional trust \\
\hline Trust in online-banking & 1 & & \\
services & $0.57^{*}$ & 1 & \\
Corporate image & $0.66^{*}$ & 0.38 & 1 \\
Institutional trust & & &
\end{tabular}

* Significant at 0.05 level.

The correlation matrix indicates the strength of association among variables and also indicates multicollinearity issues in data (Gujarati, 2003). The correlation matrix findings showed a moderate association between variables, thereby eliminating the possibility of multicollinearity. In order to test the hypotheses of this study, PLS-SEM is utilized to study the relationship between corporate image and trust in online banking services with the mediation effect of institutional trust. The following Table illustrates the findings of PLS-SEM.

For the first path, the results of path analysis showed the value of $\mathrm{R}^{2}$ as $59 \%$, where corporate image and institutional trust were regressed collectively with the trust in online banking services. In other words, variation in corporate image and institutional trust explains trust in online banking services for Iraqis by 59\%. Further analysis showed a significant positive $(\beta=0.098 \& p$-value $=0.00)$ relationship between corporate image and trust in online banking services. Putting it another way, a one-unit increase (decrease) in corporate image, ceteris paribus, would increase (decrease) the trust level of customers for online banking services by $9 \%$. 
Jadah, H. M., Alghanimi, M. H. A., \& Al-Husainy, N. H. M.

Table 5. PLS-SEM

\begin{tabular}{|c|c|c|c|c|c|c|c|c|c|}
\hline \multirow[b]{3}{*}{$\begin{array}{l}\text { Corporate } \\
\text { image }\end{array}$} & \multicolumn{3}{|c|}{ Institutional trust } & \multicolumn{3}{|c|}{$\begin{array}{l}\text { Trust in online banking } \\
\text { services }\end{array}$} & \multicolumn{3}{|c|}{$\begin{array}{l}\text { Total effect } \\
\text { Trust in online banking } \\
\text { services }\end{array}$} \\
\hline & SE & $\beta$ & P-value & SE & $\beta$ & P-value & SE & $\beta$ & P-value \\
\hline & 0.321 & 0.119 & 0.00 & 0.259 & 0.098 & 0.00 & 0.953 & 0.197 & 0.00 \\
\hline $\begin{array}{l}\text { Institutional } \\
\text { trust }\end{array}$ & & & & 0.672 & 0.236 & 0.00 & & & \\
\hline $\mathrm{R}^{2}$ & $0.43 * *$ & & & $0.59 *$ & & & $0.71 *$ & & \\
\hline & & & Total effe & & Direct ef & fect & Indirect $\mathrm{e}$ & ffect & \\
\hline Variables & & & B & $\rho$ & $\beta$ & $\mathrm{P}$ & $\beta$ & P-LL & P-UL \\
\hline Institutional & & & 0.197 & 0.00 & 0.119 & 0.01 & 0.078 & 0.00 & 0.113 \\
\hline
\end{tabular}

*Significant at $0.05 ; * *$ significant at 0.01 level; SE refers to standard error.

The result of the current paper is in line with Melewar et al. (2017) and Oliveira et al. (2017); these authors also found a significant positive relationship between corporate image and customer trust in products/services. The result also showed a significant positive $(\beta=0.236 \&$ $\mathrm{p}$-value $=0.00)$ relationship between institutional trust and trust in online banking services. This result is in accordance with the studies of Boateng (2017), Maduku (2016), and Moin et al. (2017). These studies concluded that improving institutional trust would significantly improve trust in services, particularly financial services.

The finding for path- 2 of PLS-SEM pointed out a value of $43 \%$ for $\mathrm{R}^{2}$, meaning that corporate image explains $43 \%$ of the variation in institutional trust. The path-2 approach also pointed to a significant positive $(\beta=0.119 \& \mathrm{P}=0.00)$ association between corporate image and institutional trust. The $\mathrm{R}^{2}$ value for path-3 of PLS-SEM, where institutional trust plays the role of mediator between corporate image and trust in online banking services, is $71 \%$. Again, findings pointed out a significant positive association between corporate image and trust in online banking services with the mediation of institutional trust. In order to check the mediation of institutional trust, a bias-corrected bootstrapping technique is utilized. The findings for mediation showed that institutional trust mediates the association between corporate image $(\beta=0.078 \&$ P-value between 0.00 to 0.113 ) and trust in online banking services. The possible explanation for these significant positive relationships might be that the corporate image is an accumulation of customers' experiences developed over time. If the company keeps its promises, that will result in positive word of mouth and trust in the company.

Further, if the institutional setting is strong in the country, companies 
\begin{tabular}{l|l|l} 
Management \& Economics Research Journal & Vol. 3 No. 1 (2021) & pp. 60-75 \\
\hline
\end{tabular}

have to answer for any wrongdoing. The trust level of customers in any offering in the country would be much higher. Hence, if a regular banking company starts internet banking that has previously been known for fulfilling its commitments and promises and the institutional setting is strong, then it would attract a wider audience quickly.

\section{Conclusion}

Trust is one of the main factors influencing the customer's purchase intention or service utilization. This paper examines the mediation influence of institutional trust between corporate image and trust in online banking services for Iraqi customers. In order to meet the objective of this study, the study data were collected through the distribution of 450 to customers of the banks working in Iraq, out of which 372 were utilized to examine the hypothesis. The PLS-SEM approach is utilized for estimation purposes. The path-1 results prove a significant positive association between corporate image, institutional trust, and online banking services. Results for path-2 also revealed a significant positive association between institutional trust and trust in online banking sectors. Finally, the bias-corrected bootstrapping method confirmed the mediation influence of institutional trust between corporate image and trust in online banking services.

The current study has important repercussions for the financial sector, especially for bankers and policymakers. From an administrative perspective, this study highlighted that corporate image plays a vital role in customer service utility intention. Therefore, banking companies need to make only those promises which they can keep. At the same time, administrators need to improve their infrastructure to make it more secure because security matters a lot in financial transactions, and customers would place higher trust if they are given assurance about the security of their online banking system. From the perspective of policymakers, the banking industry provides resources to accelerate economic growth; therefore, policymakers need to make policies to improve the institutional setting because stringent institutional settings would serve as a safety net for customers.

\section{Declaration of conflicting interests}

The author(s) declared no potential conflicts of interest with respect to the research, authorship, and/or publication of this article. 
Jadah, H. M., Alghanimi,

M. H. A., \& Al-Husainy, N. H. M.

\section{References}

Adams, M., Andersson, J., Andersson, L.-F., \& Lindmark, M. (2009). Commercial Banking, Insurance and Economic Growth in Sweden between 1830 and 1998. Accounting, Business \& Financial History, 19(1), 21-38. https://doi.org/10.1080/09585200802667139

Adeniran, A., Jadah, H., \& Mohammed, N. (2020). Impact of Information Technology on Strategic Management in the Banking Sector of Iraq. Insights into Regional Development, 2(2), 592-601.

Alalwan, A. A., Dwivedi, Y. K., Rana, N. P. P., \& Williams, M. D. (2016). Consumer adoption of mobile banking in Jordan: Examining the role of Usefulness, Ease of Use, Perceived Risk and Self-efficacy. Journal of Enterprise Information Management, 29(1), 118-139.

Ali, A. B. (2018) Banks, Credit and Financial Depth between Iraq and the International Experience, Central Bank of Iraq, Journal of Monetary and Financial Studies, 3, 31-63.

Alvin, N. N. (2017). The Effectiveness of Online Advertisement on Consumer Decision: A Case of Radio Africa Group Limited Nairobi, Kenya. United States International University.

Ansah, M. O., \& Chinomona, R. (2017). Analysis of Market Orientation on Business Performance in the Multinational Service Industries. Journal of Social Sciences, 1-14. https://doi.org/10.3844/jssp.2017

Boateng, F. D. (2017). Institutional Trust and Performance: A study of the Police in Ghana. Australian \& New Zealand Journal of Criminology, 1-19. https://doi.org/10.1177/0004865817712335

Bruggen, M. van. (2014). The Corporate Identity and Corporate Image of KLM A Gap Analysis. History, Culture and Communication. Erasmus University Rotterdam.

D'agostino, R. B., Belanger, A., \& D'Agostino Jr, R. B. (1990). A Suggestion for Using Powerful and Informative Tests of Normality. The American Statistician, 44(4), 316-321.

Ennew, C., Kharouf, H., \& Sekhon, H. (2011). Trust in UK Financial Services: A Longitudinal Analysis. Journal of Financial Services Marketing, 16(1), 65-75. https://doi.org/10.1057/fsm.2011.8

Fuglsang, L., \& Jagd, S. (2015). Making Sense of Institutional Trust in 
\begin{tabular}{l|l|l} 
Management \& Economics Research Journal & Vol. 3 No. 1 (2021) & pp. 60-75
\end{tabular}

Organizations: Bridging Institutional Context and Trust. The organization, 22(1), 23-39. https://doi.org/10.1177/1350508413496577

Gujarati, D. N. (2003). Basic Econometrics (Fourth). New York: McGrawHiII/Irwin.

Guo, C., Kulviwat, S., Zhu, J., \& Wang, Y. J. (2017). Competing in an Emerging Market: Antecedents and Consequences of Market Orientation and the Role of Environmental Factors. Journal of Strategic Marketing, 1-20. https://doi.org/10.1080/0965254X.2017.1411386

Hair, J. F., Matthews, L. M., Matthews, R. L., \& Sarstedt, M. (2017). PLSSEM or CB-SEM : Updated Guidelines on Which Method to Use. International Journal Multivariate Data Analysis, 1(2), 107-123. https://doi.org/10.1504/IJMDA.2017.087624

Horng, J.-S., Liu, C.-H., Chou, S.-F., Tsai, C.-Y., \& Hu, D. C. (2018). Does

Corporate Image Really Enhance Consumer's Behavioural Intentions? Asia Pacific Journal of Tourism Research, 23(10), 10081020. https://doi.org/10.1080/10941665.2018.1513946

IMF. (2019). Iraq Selected Issues. IMF Country Report No. 19/249, 1-47.

Jadah, H. M., Alghanimi, M. H., Al-Dahaan, N. S., \& Al-Husainy, N. H. (2020). Internal and External Determinants of Iraqi Banks Profitability. Banks and Bank Systems, 15(2), 79-93. http://dx.doi.org/10.21511/bbs.15(2).2020.08.

Jadah, H. M., Murugiah, L. A. \& Adzis, A. B. A. (2016). Board Characteristics and Bank Performance: Evidence from Iraq. Journal of Independent Studies and Research: Management, Social Sciences and Economics, 14(1), 29-41.

Jadah, H. M., Mohammed, N. H., Hasan, M. M., \& Adetayo O. A. (2020). The Impact of the Political Instability on Bank's Performance: Evidence from Iraq. The Iraqi Magazine for Managerial Sciences, 16(65), 228-240.

Jaworski, B. J., \& Kohli, A. K. (2017). Conducting Field-based, DiscoveryOriented Research: Lessons from our Market Orientation Research Experience. AMS Review, 7(1-2), 4-12. https://doi.org/10.1007/s13162-017-0088-5

Kasim, A., Ekinci, Y., Altinay, L., \& Hussein, K. (2018). Impact of Market 
Jadah, H. M., Alghanimi,

M. H. A., \& Al-Husainy, N. H. M.

Orientation, Organizational Learning and Market Conditions on Small and Medium-size Hospitality Enterprises. Journal of Hospitality Marketing and Management, 27(07), 1-21. https://doi.org/10.1080/19368623.2018.1438955

Koksal, M. H. (2016). The Intentions of Lebanese Consumers to Adopt Mobile Banking. International Journal of Bank Marketing, 34(3), 327-346.

Litzinger, T. A., Lee, S. H., Wise, J. C., \& Felder, R. M. (2005). Applications, Reliability and Validity of the Index of Learning Styles. In Int. J. Egng ED (pp. 103-112). USA: American Society for Engineering Education.

Maduku, D. K. (2016). the Effect of Institutional Trust on Internet Banking Acceptance: Perspectives of South African Banking Retail Customers. South African Journal of Economic and Management Sciences, 19(4), 533-548. https://doi.org/10.17159/22223436/2016/v19n4a5

Mahmoud, M. A., Blankson, C., Owusu-Frimpong, N., Nwankwo, S., \& Trang, T. P. (2016). Market Orientation, Learning Orientation and Business Performance. International Journal of Bank Marketing, 34(5), 623-648. https://doi.org/10.1108/IJBM-04-2015-0057

Malaysian Association of Risk and Insurance. (2018). Deputy Governor's Opening Speech at the Malaysian Association of Risk and Insurance Management (MARIM) Conference 2018. Retrieved July 22, 2018, from

https://www.bnm.gov.my/index.php?ch=en_speech\&pg=en_speech $\& \mathrm{ac}=803$ \&lang $=$ en

Mcknight, D. H., Choudhury, V., \& Kacmar, C. J. (2000). Trust in Ecommerce Vendors: A two-stage model. Proceedings of the TwentyFirst International Conference on Information Systems. Association for Information Systems, (Heider 1958), 532-536.

McNeish, J. (2015). Consumer Trust and Distrust: Retaining Paper Bills in Online Banking. International Journal of Bank Marketing, 33(1), 522. https://doi.org/http://dx.doi.org/10.1108/MRR-09-2015-0216 Melewar, T. C., Gupta, P. F. S., Kitchen, P. J., \& Foroudi, M. M. (2017). Integrating Identity, Strategy and Communications for Trust, Loyalty and Commitment. International Journal for Marketing, 51(3), 572- 
\begin{tabular}{l|l|l} 
Management \& Economics Research Journal & Vol. 3 No. 1 (2021) & pp. 60-75
\end{tabular}

604. https://doi.org/http://dx.doi.org/10.1108/MRR-09-2015-0216

Moin, S. M. A., Devlin, J. F., \& McKechnie, S. (2017). Trust in Financial Services: The Influence of Demographics and Dispositional Characteristics. Journal of Financial Services Marketing, 22(2), 64 76. https://doi.org/10.1057/s41264-017-0023-8

Mostafa, R. (2017). Does Corporate Image Really Matter in Service Recovery Context. International Journal of Customer Relationship Marketing and Management, 8(1), 1-14.

Narver, J. C., \& Slater, S. F. (1990). The Effect of a Market Orientation on Business Profitability. Journal of Marketing, 54(4), 20-35. https://doi.org/10.2307/1251757

Oliveira, T., Alhinho, M., Rita, P., \& Dhillon, G. (2017). Modelling and Testing Consumer Trust Dimensions in E-commerce. Computers in Human Behavior, 71 $153-164$.

https://doi.org/10.1016/j.chb.2017.01.050

Pauline, W. J., Esterik-Plasmeijer, V., \& Raaij, W. F. van. (2017). Banking System Trust, Bank Trust, and Bank Loyalty. International Journal of Banking Marketing, 35(1), 97-111. https://doi.org/10.1108/EUM0000000001122

Sikdar, P., Kumar, A., \& Makkad, M. (2015). Online Banking Adoption: A Factor Validation and Satisfaction Causation Study in the Context of Indian Banking Customers. International Journal of Bank Marketing, 33(6), 760-785. https://doi.org/http://dx.doi.org/10.1108/MRR-09-2015-0216

Singh, S., \& Ranchhod, A. (2004). Market Orientation and Customer Satisfaction: Evidence from British Machine Tool Industry. Industrial Marketing Management, 33(2), 135-144. https://doi.org/10.1016/S0019-8501(03)00056-7

Tse, A. C. B., Sin, L. Y. M., Yau, O. H. M., Lee, J. S. Y., \& Chow, R. (2003). Market Orientation and Business Performance in a Chinese Business Environment. Journal of Business Research, 56, 227-239. https://doi.org/10.1016/S0148-2963(01)00230-2

Wang, S. W., Ngamsiriudom, W., \& Hsieh, C. H. (2015). Trust Disposition, Trust Antecedents, Trust, and Behavioural Intention. Service Industries Journal, 35(10), $555-572$. https://doi.org/10.1080/02642069.2015.1047827 
Yu, P. L., Balaji, M. S., \& Khong, K. W. (2017). Building Trust in Internet Banking: A trustworthiness Perspective. Industrial Management \& Data Systems, 115(2), 235-252.

Yusuf Dauda, S., \& Lee, J. (2015). Technology Adoption: A conjoint Analysis of Consumers' Preference on Future Online Banking Services. Information Systems, 53, 1-15. Retrieved from http://dx.doi.org/10.1016/j.is.2015.04.006

Zameer, H., Tara, A., Kausar, U., \& Mohsin, A. (2015). Impact of Service Quality, Corporate Image and Customer Satisfaction Towards Customers' Perceived Value in the Banking Sector in Pakistan. International Journal of Bank Marketing, 33(4), 442-456. 